\title{
Dynamics of ecosystem carbon stocks during vegetation restoration on the Loess Plateau of China
}

\author{
WANG Kaibo ${ }^{1}$, DENG Lei $^{2}$, REN Zongping ${ }^{2,3 *}$, SHI Weiyu ${ }^{1}$, CHEN Yiping ${ }^{1}$, \\ SHANG-GUAN Zhouping ${ }^{2}$ \\ ${ }^{1}$ State Key Laboratory of Loess and Quaternary Geology, Institute of Earth Environment, Chinese Academy of Sciences, Xi'an \\ 710075, China; \\ ${ }^{2}$ State Key Laboratory of Soil Erosion and Dryland Farming on the Loess Plateau, Northwest A\&F University, Yangling \\ 712100, China; \\ ${ }^{3}$ State Key Laboratory Base of Eco-Hydraulic Engineering in Arid Area, Xi'an University of Technology, Xi'an 710048, China
}

\begin{abstract}
In the last few decades, the Loess Plateau had experienced an extensive vegetation restoration to reduce soil erosion and to improve the degraded ecosystems. However, the dynamics of ecosystem carbon stocks with vegetation restoration in this region are poorly understood. This study examined the changes of carbon stocks in mineral soil $(0-100 \mathrm{~cm})$, plant biomass and the ecosystem (plant and soil) following vegetation restoration with different models and ages. Our results indicated that cultivated land returned to native vegetation (natural restoration) or artificial forest increased ecosystem carbon sequestration. Tree plantation sequestered more carbon than natural vegetation succession over decades scale due to the rapid increase in biomass carbon pool. Restoration ages had different effects on the dynamics of biomass and soil carbon stocks. Biomass carbon stocks increased with vegetation restoration age, while the dynamics of soil carbon stocks were affected by sampling depth. Ecosystem carbon stocks consistently increased after tree plantation regardless of the soil depth; but an initial decrease and then increase trend was observed in natural restoration chronosequences with the soil sampling depth of $0-100 \mathrm{~cm}$. Moreover, there was a time lag of about 15-30 years between biomass production and soil carbon sequestration in 0-100 cm, which indicated a long-term effect of vegetation restoration on deeper soil carbon sequestration.
\end{abstract}

Keywords: ages; carbon stocks; natural vegetation restoration; tree plantation; Loess Plateau

Citation: WANG Kaibo, DENG Lei, REN Zongping, SHI Weiyu, CHEN Yiping, SHANG-GUAN Zhouping. 2016. Dynamics of ecosystem carbon stocks during vegetation restoration on the Loess Plateau of China. Journal of Arid Land, 8(2): $207-220$. doi: 10.1007/s40333-015-0091-3

Land use change plays a key role in the terrestrial ecosystem carbon (C) cycle by influencing the inputs and decomposition of organic matter. Deforestation is regarded as a major factor that causes significant declines in the terrestrial $\mathrm{C}$ pool. Conversely, vegetation restoration on former cultivated land has been recognized as an effective method for $\mathrm{C}$ sequestration (Laganière et al., 2010; Li et al., 2012). Recently, many studies quantified and evaluated C stock and its variation after vegetation restoration, but most of the studies focused on comparing the soil organic carbon (SOC) differences among various land use types, while the variations of vegetation $\mathrm{C}$ pool were neglected (Wei et al., 2012; Marín-Spiotta and Sharma, 2013; Guidi et al., 2014). Those studies probably lead to incomplete evaluation of $\mathrm{C}$ sequestration after vegetation restoration. In addition, natural vegetation restoration and tree plantation are two important remediation measures that

\footnotetext{
*Corresponding author: REN Zongping (E-mail: renzongping@163.com)

Received 2015-04-20; revised 2015-08-12; accepted 2015-08-25

(C) Xinjiang Institute of Ecology and Geography, Chinese Academy of Sciences, Science Press and Springer-Verlag Berlin Heidelberg 2016
} 
were adopted in formerly degraded ecosystems to help the recovery of ecosystem C pool (Jin et al., 2014). Whether tree plantation on former cultivated land has a higher carbon sequestration potential than natural vegetation restoration is still not answered in many regions by now (Tremblay and Ouimet, 2013), there is a great need to compare the $\mathrm{C}$ sequestration potential between natural vegetation restoration and tree plantation in different regions.

The $\mathrm{C}$ sink effect of vegetation restoration is greatly influenced by restoration age. Existing studies of $\mathrm{C}$ dynamics along with vegetation restoration mainly focused on the first few decades following abandonment, with only a few studies extending beyond 60 years (Foote and Grogan, 2010; Laganière et al., 2010). However, $C$ accumulation occurs much more slowly during reforestation than $\mathrm{C}$ loss following deforestation. A study shows that more than 120 years is needed to reach $\mathrm{C}$ equilibrium after converting cropland to forest in the temperate zone (Poeplau et al., 2011). In a meta-analysis, Laganière et al. (2010) concluded that 35 to more than 100 years were required to compensate for the loss of SOC associated with tree plantation establishment in boreal and temperate regions. Therefore, long term $\mathrm{C}$ sequestration research is specifically important for improving our understanding of the $\mathrm{C}$ pool dynamics after vegetation restoration and for enhancing the predictive accuracy of $\mathrm{C}$ models.

Although substantial amount of $\mathrm{C}$ were stored in the subsoil, the effect of land use changes on deep C stocks has been poorly addressed (Deng et al., 2014). Most of researches sampled soils to a depth of less than $30 \mathrm{~cm}$ (Shi et al., 2013; Jandl et al., 2014). Land use change influences SOC not only in the top soil but also in the subsoil (Deng et al., 2014). Jandl et al. (2014) reviewed the current status and obstacle in global SOC monitoring, and suggested that the shallow sampling depths introduce large uncertainties into global SOC pool estimates. SOC at shallow depths are supposed to be more responsive to land use change than SOC in deep soil because the upper soil holds the majority of metabolically active soil microorganisms (Don et al., 2011; Shi et al., 2013). Therefore, shallow sampling may lead to overestimations of land use change effects on soil C (Don et al., 2011). Although the SOC pool in the subsoil is less dynamic over time, the deep soil may have a higher potential to sequester $\mathrm{CO}_{2}$ from the atmosphere by forming silt- and clay-associated soil $\mathrm{C}$ through the stabilizing mechanisms of soil organic matter and the recalcitrance of plant residues (Lorenz et al., 2011). Since the dynamics of deep SOC resulting from land use change are poorly understood, more attention should be given to examining effects on $\mathrm{C}$ in deep soil to reduce the uncertainty in our understanding of the $\mathrm{C}$ cycle in terrestrial ecosystems.

The Loess Plateau of China is known to be subject to severe soil erosion with a mean annual soil erosion rate as high as $5,000-10,000 \mathrm{t} /\left(\mathrm{km}^{2} \cdot \mathrm{a}\right)$ (Lu et al., 2013). In different eras, vegetation on the Loess Plateau experienced various degrees of destruction and recovery because of cultivation, wars, immigration and emigration, and soil and water conservation implementation. In recent decades, a series of ecological restoration programs such as the "Grain for Green" program have resulted in land use changes on the Loess Plateau (Feng et al., 2013). There are a variety of vegetation restoration models and age-sequences in this region that are ideal sites for investigating the effect of vegetation restoration on ecosystem $\mathrm{C}$ dynamics. Currently, the SOC dynamics in response to the land use change have been extensively investigated at local and regional scales on the Loess Plateau (Liu et al., 2011; Jia et al., 2012; Zhang et al., 2013; Deng et al., 2014). However, most of these studies focused on the changes of soil carbon pool while neglected the variation of vegetation carbon pool. Moreover, studies concerning the long term effects of vegetation restoration on ecosystem carbon pool were still rare on the Loess Plateau. Therefore, the aims of the present study were to: (1) compare the effect of natural vegetation restoration and tree plantation on ecosystem (plant and soil) C dynamics; (2) investigate the short and long term changes in ecosystem $\mathrm{C}$ stocks; and (3) examine the temporal pattern of $\mathrm{C}$ stocks with the soil depth.

\section{Materials and methods}

\subsection{Study area}

To explore the $\mathrm{C}$ stock dynamics during vegetation restoration, we selected two natural succession and one tree plantation chronosequences on the Loess Plateau of China (Table 1). Among the three chronosequences, the short term natural regeneration and tree plantations 
sequence are located in the Zhifanggou watershed in Ansai county, Shaanxi province; and the long term natural regeneration sequence is located in the Lianjiabian Forest Farm in Heshui county, Gansu province (Fig. 1). Both study areas have similar landforms of loess hilly topography, semi-arid continental climate and dry-land farming history that ensured comparability among the three vegetation restoration chronosequences. In the Zhifanggou watershed, the annual mean temperature is $9.1^{\circ} \mathrm{C}$ and the mean annual precipitation is $503 \mathrm{~mm}$, of which about $70 \%$ precipitation falls in July to September. Soils in the watershed are mainly loessial soil with a $\mathrm{pH}$ of $8.33-8.78$ and comprised sand, silt and clay contents at $31.3 \%, 58.2 \%$ and $10.5 \%$, respectively. The natural vegetation types are herbs and shrubs including Stipa bungeana, Bothriochloa ischaemum, Artemisia sacrorum, Potentilla acaulis, Stipa grandis, Rosa xanthina, Spiraea pubescens and Hippophae rhamnoides, while the tree plantations in the study area consist of Robinia pseudoacacia, Populus simonii, Caragana microphylla and Platycladus orientalis. The farmlands are mainly planted with millet, corn, soybeans and potatoes and the production are absolutely depend on rainfalls. The Zhifanggou watershed has undergone vegetation restoration and construction in different periods since the 1970s. A natural vegetation restoration chronosequence and a tree plantation chronosequence were selected in the Zhifanggou watershed for comparing the effect of restoration models on ecosystem $\mathrm{C}$ stock dynamics. The ages of each chronosequence were determined by consulting the village elders. The natural vegetation restoration chronosequence aged as 1, 7, 13, 20 and 30 years after farmland was abandoned (chronosequence 1); while the tree plantation chronosequence were at the ages of 7 , 15, 24, 36 and 48 years after Robinia pseudoacacia was planted (Chronosequence 2). The vegetation information for selected sites is listed in Table 2.

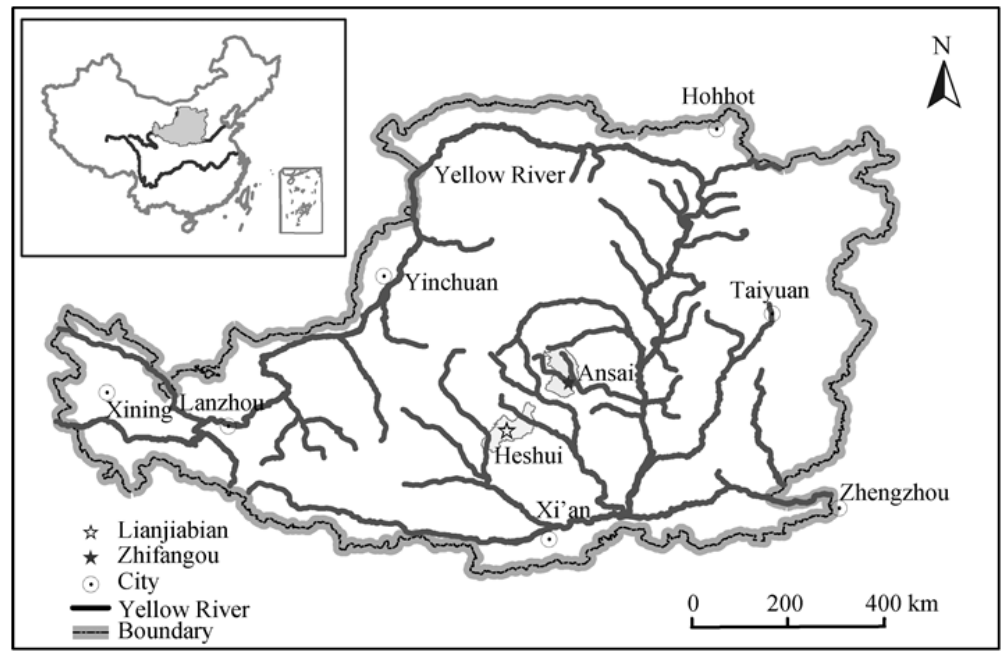

Fig. 1 Location of sampling sites on the Loess Plateau of China

In the Lianjiabian Forest Farm, the annual mean temperature is $7.4^{\circ} \mathrm{C}$ and the mean annual precipitation is $587 \mathrm{~mm}$. The soils are largely loessal and developed from primary or secondary loess parent materials. Sand, silt and clay contents are $13.9 \%, 79.5 \%$ and $6.6 \%$, respectively. Soil $\mathrm{pH}$ ranges from 7.92-8.31. Natural vegetation in the region is deciduous broad-leaf forests which regenerated in the former cultivated land. Main woody plant species present here include Quercus liaotungensis, Populus davidiana and Betula platyphylla. Shrubs and herbaceous plants that are common to the region during the early recovery sequence include Sophora davidii, Hippophae rhamnoides, Rosa xanthina, Spiraea pubescens, Bothriochloa ischaemum, Carex lanceolata, Potentilla chinensis and Stipa bungeana. The long term cultivation crop types are millet, corn, potatoe and soybean. The Lianjiabian Forest Farm is located in the Ziwuling forest region. Vegetation in this region has experienced a long term natural restoration of agricultural land that was abandoned by residents when they emigrated during the national conflict of 1842-1866. However, some people immigrated here and reclaim the lands after the 1940s because of wars and 
famines. Some farmland was abandoned again after the 1970s because of land transfer and ecological protection. Therefore different vegetation restoration stages can be observed in this region (Deng et al., 2013b). An age sequence of 11, 16, 22, 27, 60, 100 and 150 years (Chronosequence 3) was selected to evaluate the long term natural vegetation restoration effect on C stock dynamics on the Loess Plateau. Previous studies revealed that $Q$. liaotungensis and $P$. davidiana forests recovered about 150 and 100 years respectively, after the abandonment of cultivated land. For natural vegetation that regenerated for no more than 60 years, the restoration time were determined by interviewing local elders. Vegetation information of each age stage is also listed in Table 2.

Table 1 Geographical location, climatic, edaphic parameter, restoration models and age ranges of the three chronoseqences

\begin{tabular}{lccc}
\hline & Chronosequence 1 & Chronosequence 2 & Chronosequence 3 \\
\hline Longitude & $109^{\circ} 13^{\prime}-109^{\circ} 17^{\prime} \mathrm{E}$ & $109^{\circ} 13^{\prime}-109^{\circ} 17^{\prime} \mathrm{E}$ & $108^{\circ} 10^{\prime}-109^{\circ} 18^{\prime} \mathrm{E}$ \\
Latitude & $36^{\circ} 46^{\prime}-36^{\circ} 47^{\prime} \mathrm{N}$ & $36^{\circ} 46^{\prime}-36^{\circ} 47^{\prime} \mathrm{N}$ & $35^{\circ} 03^{\prime}-36^{\circ} 37^{\prime} \mathrm{N}$ \\
Altitude $(\mathrm{m})$ & $1,150-1,360$ & $1,150-1,360$ & $1,300-1,450$ \\
Precipitation $(\mathrm{mm})$ & 503 & 503 & 587 \\
Temperature $\left({ }^{\circ} \mathrm{C}\right)$ & 9.1 & 9.1 & 7.4 \\
Soil texture & Silt loam & Silt loam & Silt loam \\
Soil parent material & Loess & Loess & Loess \\
Restoration model & Natural & Planted & Natural \\
Prior land use & Farmland & Farmland & Farmland \\
Chronosequence stand age (year) & $1,7,13,20,30$ & $7,15,24,36,48$ & $11,16,22,27,60,100,150$ \\
\hline
\end{tabular}

\subsection{Field sampling and measurements}

The field surveys in Zhifanggou watershed and Lianjiabian Forest Farm were conducted in August 2011 and September 2012, respectively. Three plots were chosen in each age stage. The plot area was $20 \mathrm{~m} \times 20 \mathrm{~m}$ in tree sites, $5 \mathrm{~m} \times 5 \mathrm{~m}$ in shrub sites, and $2 \mathrm{~m} \times 2 \mathrm{~m}$ in herbaceous sites. The species, individual number, tree height, tree diameter at breast height, and community coverage were recorded at each plot. Above- and below-ground biomass of shrub and herbaceous sites were directly measured. In each plot, the above-ground parts were harvested and the roots at depth from 0 to $100 \mathrm{~cm}$ were sampled with a $9-\mathrm{cm}$ inner-diameter root corer. Fresh above-ground samples and parts of the dried samples from each plot were weighed to calculate the above-ground biomass by multiplying the ratio of the dry weight/fresh weight ratio by the fresh weight. The below-ground biomass was calculated as the sum of all the dried roots in soil from 0 to $100 \mathrm{~cm}$ depth. To prevent the destruction caused by harvesting tree biomass from forest ecosystem, we used allometric equations (built from studies in regions with similar climate and environmental conditions) to determine the above- and below-ground biomass of tree plantation and natural forest (Table 3) (China's State Forestry Administration, 2011). The vegetation biomass was converted into biomass $\mathrm{C}$ stocks with a recommended conversion factor of 0.48 (Eggleston et al., 2006).

Soil samples were collected with a 9-cm inner-diameter corer at the four corners and the center of each plot. The litters in each plot were cleared completely before sampling. The mineral soil layer at the depths of $0-10,10-20,20-50$ and 50-100 cm were collected and mixed to make one sample for each layer. All the soil samples were air-dried and sieved through a 2-mm screen for the determination of SOC content. In addition, undisturbed soil cores were sampled at the middle of each layer using a $5-\mathrm{cm}$ diameter and $5-\mathrm{cm}$ high-stainless steel cutting ring for measuring bulk density. Three replicates were surveyed in each plot. The content of SOC was measured using dichromate oxidation method (Kalembasa and Jenkinson, 1973). Because there was no coarse fraction $(>2 \mathrm{~mm})$ in the soil samples, the soil $\mathrm{C}$ stock was calculated using the Eq. 1 (Guo and Gifford, 2002):

$$
\mathrm{C}_{\mathrm{s}}=\mathrm{BD} \times \mathrm{SOC} \times \mathrm{D} / 10,
$$

where $\mathrm{C}_{\mathrm{s}}$ is soil $\mathrm{C}$ stock $\left(\mathrm{Mg} / \mathrm{hm}^{2}\right)$; BD is soil bulk density $\left(\mathrm{g} / \mathrm{cm}^{3}\right)$; SOC is soil organic $\mathrm{C}$ content 
$(\mathrm{g} / \mathrm{kg})$; and $\mathrm{D}$ is soil thickness $(\mathrm{cm})$. The total amount of soil $\mathrm{C}$ stock above a given soil depth was estimated as the sum of the products of SOC, BD and D above that depth. The ecosystem C stock was the sum of soil $\mathrm{C}$ stock and plant $\mathrm{C}$ stock in each restoration stage.

Table 2 Site conditions and vegetation information of each restoration stage in the three chronoseqences

\begin{tabular}{|c|c|c|c|c|c|c|}
\hline & $\begin{array}{l}\text { Restoration } \\
\text { age (year) }\end{array}$ & $\begin{array}{c}\text { Slope } \\
\text { gradient }\left(^{\circ}\right)\end{array}$ & $\begin{array}{l}\text { Slope } \\
\text { position }\end{array}$ & Aspect & $\begin{array}{l}\text { Coverage } \\
(\%)\end{array}$ & Dominant plant species \\
\hline \multirow[t]{5}{*}{ Chronosequence 1} & 1 & $20-27$ & $\begin{array}{l}\text { Upper of } \\
\text { the slope }\end{array}$ & $\begin{array}{l}\text { Semi-sunny } \\
\text { slope }\end{array}$ & 8.8 & Artemisia scoparia \\
\hline & 7 & $25-28$ & $\begin{array}{l}\text { Upper of } \\
\text { the slope }\end{array}$ & $\begin{array}{l}\text { Semi-shady } \\
\text { slope }\end{array}$ & 19.4 & Lespedeza bicolor+Setaira viridis \\
\hline & 13 & $18-23$ & $\begin{array}{l}\text { Upper of } \\
\text { the slope }\end{array}$ & $\begin{array}{l}\text { Semi-shady } \\
\text { slope }\end{array}$ & 24.4 & $\begin{array}{l}\text { Agropyron cristatum }+ \text { Heteropappus } \\
\text { altaicus }\end{array}$ \\
\hline & 20 & $18-25$ & $\begin{array}{l}\text { Upper of } \\
\text { the slope }\end{array}$ & $\begin{array}{l}\text { Semi-shady } \\
\text { slope }\end{array}$ & 41.0 & $\begin{array}{l}\text { Artemisia sacrorum }+ \text { Bothriochloa } \\
\text { ischaemum }\end{array}$ \\
\hline & 30 & $27-32$ & $\begin{array}{l}\text { Upper of } \\
\text { the slope }\end{array}$ & $\begin{array}{l}\text { Semi-sunny } \\
\text { slope }\end{array}$ & 48.0 & $\begin{array}{l}\text { Bothriochloa ischaemum }+ \text { Stipa } \\
\text { bungeana }\end{array}$ \\
\hline \multirow[t]{5}{*}{ Chronosequence 2} & 7 & $5-10$ & $\begin{array}{l}\text { Top of the } \\
\text { slope }\end{array}$ & $\begin{array}{l}\text { Semi-sunny } \\
\text { slope }\end{array}$ & 25.0 & $\begin{array}{l}\text { Robinia pseudoacacia+Artemisia } \\
\text { scoparia+Setaris viridis }\end{array}$ \\
\hline & 15 & $20-25$ & $\begin{array}{l}\text { Upper of } \\
\text { the slope }\end{array}$ & $\begin{array}{l}\text { Semi-sunny } \\
\text { slope }\end{array}$ & 58.0 & $\begin{array}{l}\text { Robinia pseudoacacia }+ \text { Artemisia } \\
\text { scoparia+Artemisia gmelini }\end{array}$ \\
\hline & 24 & $15-20$ & $\begin{array}{l}\text { Middle of } \\
\text { the slope }\end{array}$ & $\begin{array}{l}\text { Semi-sunny } \\
\text { slope }\end{array}$ & 75.0 & $\begin{array}{l}\text { Robinia pseudoacacia+Artemisia } \\
\text { gmelini }+ \text { Artemisia scoparia }\end{array}$ \\
\hline & 36 & $20-25$ & $\begin{array}{l}\text { Upper of } \\
\text { the slope }\end{array}$ & Sunny slope & 90.0 & $\begin{array}{l}\text { Robinia pseudoacacia+Carex } \\
\text { lancifolia +Artemisia gmelini }\end{array}$ \\
\hline & 48 & $20-25$ & $\begin{array}{l}\text { Upper of } \\
\text { the slope }\end{array}$ & Sunny slope & 95.0 & $\begin{array}{l}\text { Robinia pseudoacacia }+ \text { Artemisia } \\
\text { gmelini+Carex lancifolia }\end{array}$ \\
\hline \multirow[t]{7}{*}{ Chronosequence 3} & 11 & $10-15$ & $\begin{array}{l}\text { Top of the } \\
\text { slope }\end{array}$ & Sunny slope & 40.0 & $\begin{array}{l}\text { Artemisia giraldii }+ \text { Artemisia } \\
\text { gmelini }\end{array}$ \\
\hline & 16 & $5-10$ & $\begin{array}{l}\text { Top of the } \\
\text { slope }\end{array}$ & Sunny slope & 75.0 & $\begin{array}{l}\text { Artemisia giraldii }+ \text { Potentilla } \\
\text { chinensis }\end{array}$ \\
\hline & 22 & $10-15$ & $\begin{array}{l}\text { Upper of } \\
\text { the slope }\end{array}$ & $\begin{array}{l}\text { Semi-sunny } \\
\text { slope }\end{array}$ & 80.0 & $\begin{array}{l}\text { Bothriochloa ischaemum+Sophora } \\
\text { viciifolia }\end{array}$ \\
\hline & 27 & $5-10$ & $\begin{array}{l}\text { Top of the } \\
\text { slope }\end{array}$ & Sunny slope & 85.0 & $\begin{array}{l}\text { Bothriochloa ischaemum } \\
+ \text { Hippophae rhamnoides }\end{array}$ \\
\hline & 60 & $10-15$ & $\begin{array}{l}\text { Top of the } \\
\text { slope }\end{array}$ & $\begin{array}{l}\text { Semi-sunny } \\
\text { slope }\end{array}$ & 85.0 & $\begin{array}{l}\text { Hippophae rhamnoides+Carex } \\
\text { lancifolia }\end{array}$ \\
\hline & 100 & $10-15$ & $\begin{array}{l}\text { Top of the } \\
\text { slope }\end{array}$ & $\begin{array}{l}\text { Semi-shady } \\
\text { slope }\end{array}$ & 85.0 & $\begin{array}{l}\text { Populus davidiana+Spiraea } \\
\text { schneideriana+Carex lancifolia }\end{array}$ \\
\hline & 150 & $10-15$ & $\begin{array}{l}\text { Upper of } \\
\text { the slope }\end{array}$ & $\begin{array}{l}\text { Semi-shady } \\
\text { slope }\end{array}$ & 90.0 & $\begin{array}{l}\text { Quercus liaotungensis }+ \text { Rosa } \\
\text { xanthina+Carex lancifolia }\end{array}$ \\
\hline
\end{tabular}

Table 3 The allometric equations and location information of the three forest types

\begin{tabular}{lccc}
\hline Forest type & R. pseudoacacia & P. davidiana & Q. liaotungensis \\
\hline Stem biomass & $\mathrm{Ws}=0.02583 \times\left(\mathrm{D}^{2} \times \mathrm{H}\right)^{0.95405}$ & $\mathrm{Ws}=0.03388 \times\left(\mathrm{D}^{2} \times \mathrm{H}\right)^{0.8765}$ & $\mathrm{Ws}=0.04930 \times\left(\mathrm{D}^{2} \times \mathrm{H}\right)^{0.8514}$ \\
Branch biomass & $\mathrm{Wb}=0.00464 \times \mathrm{D}^{3.21307}$ & $\mathrm{~Wb}=0.00042 \times\left(\mathrm{D}^{2} \times \mathrm{H}\right)^{1.387}$ & $\mathrm{~Wb}=0.004917 \times \mathrm{D}^{3.09503}$ \\
Leaf biomass & $\mathrm{Wl}=0.0234 \times \mathrm{D}^{1.92768}$ & $\mathrm{Wl}=0.0003 \times\left(\mathrm{D}^{2} \times \mathrm{H}\right)^{1.2043}$ & $\mathrm{Wl}=0.018504 \times \mathrm{D}^{2.1739}$ \\
Root biomass & $\mathrm{Wr}=0.01779 \times \mathrm{D}^{2.6448}$ & $\mathrm{Wr}=0.0215 \times\left(\mathrm{D}^{2} \times \mathrm{H}\right)^{0.7757}$ & $\mathrm{Wr}=0.144894 \times \mathrm{D}^{1.7911}$ \\
Location & $\mathrm{Changwu}$, Shannxi & Datong, Qinghai & Xunyin, Shannxi \\
Precipitation $(\mathrm{mm})$ & 584 & 523 & 600 \\
Temperature $\left({ }^{\circ} \mathrm{C}\right)$ & 9.1 & 4.9 & 9.0
\end{tabular}

Note: The allometric equations were adopted from "Carbon sinks metering and monitoring guidelines of afforestation projects" which was published by China's State Forestry Administration (2011). 


\subsection{Statistical analysis}

One-way ANOVA was used to analyze the differences of the SOC content, soil C stocks, vegetation $\mathrm{C}$ stocks and ecosystem $\mathrm{C}$ stocks among the different restoration ages. Differences were evaluated at the 5\% significance level. When significance was observed at the $P<0.05$ level, LSD test was used for multiple comparisons. All the statistical analyses were performed using the software program SPSS, ver. 16.0 (SPSS Inc., Chicago, IL, USA).

\section{Results}

\subsection{Dynamics of soil C stocks}

In chronosequence 1, the SOC contents were 3.69-5.56 and $1.67-2.26 \mathrm{~g} / \mathrm{kg}$ in the depths of $0-10$ and $50-100 \mathrm{~cm}$ (Fig. 2). After 30 years of natural restoration, the SOC contents did not significantly increase in the depth of $0-100 \mathrm{~cm}$ except for in the top $10 \mathrm{~cm}$ (Fig. 2a). The soil C stocks were $4.57-6.00 \mathrm{Mg} / \mathrm{hm}^{2}$ in $0-10 \mathrm{~cm}$ and $27.59-35.75 \mathrm{Mg} / \mathrm{hm}^{2}$ in $0-100 \mathrm{~cm}$ in chronosequence 1. Changes in soil $\mathrm{C}$ stocks in the 30 -year natural vegetation restoration were not consistent at different soil depths. The soil $\mathrm{C}$ stocks slowly increased at the depths of $0-10$ and 0 $20 \mathrm{~cm}$, while they showed initial decline and then increased at the depths of 0-50 and 0-100 cm in the 30-year natural vegetation restoration (Fig. 2b).
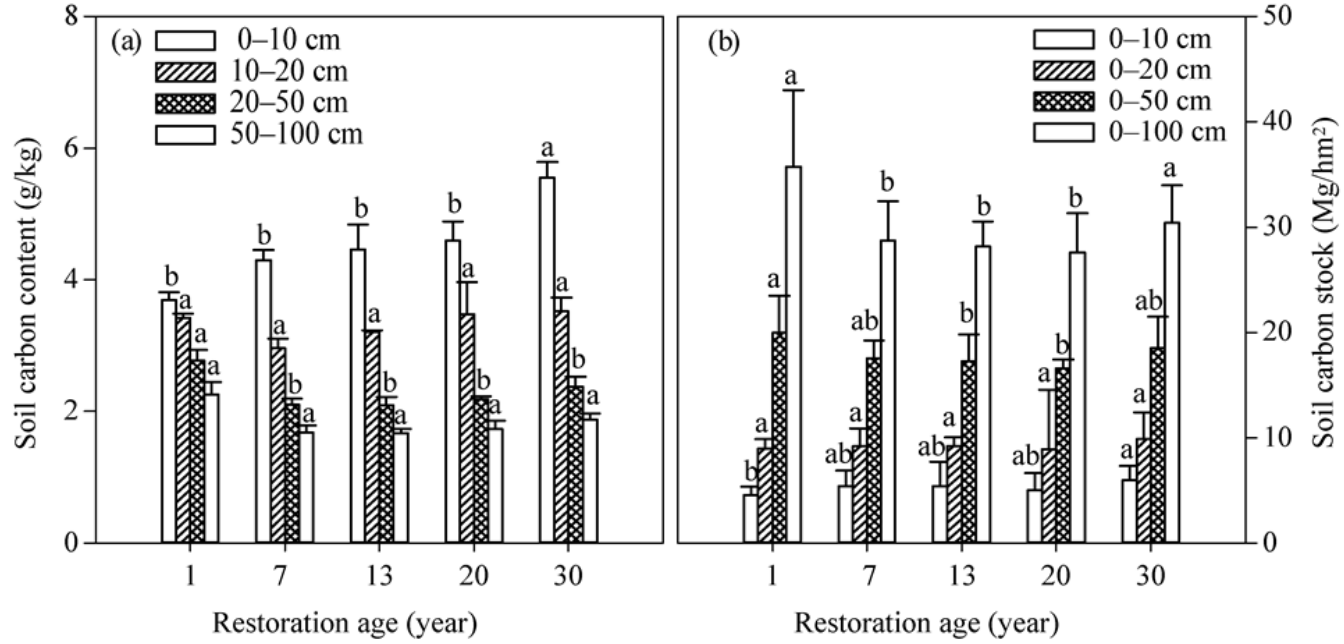

Fig. 2 Changes of soil organic carbon (SOC) content (a) and soil C stock (b) in chronosequence 1. Different letters indicate significant differences among restoration ages based on LSD test, with $P<0.05$ level.

In chronosequence 2 , the SOC contents were significantly increased by $75 \%$ from $4.69 \mathrm{~g} / \mathrm{kg}$ in 7 -year plantations to $8.20 \mathrm{~g} / \mathrm{kg}$ in beyond 48 -year plantations at the depth of $0-10 \mathrm{~cm}$. The SOC contents in 10-20 $\mathrm{cm}$ depth also exhibited a small but significant increase in the 48-year restoration (Fig. 3). However, there were minor changes at 20-50 and 50-100 cm depths in the beyond 48-year tree plantations (Fig. 3a). The soil C stocks ranged from $4.81-9.23 \mathrm{Mg} / \mathrm{hm}^{2}$ at depths of $0-10 \mathrm{~cm}$ and $32.29-36.52 \mathrm{Mg} / \mathrm{hm}^{2}$ at $0-100 \mathrm{~cm}$ in chronosequence 2 . The soil C stocks showed significant increase at the depths of 0-10, 0-20 and 0-50 cm but only minor changes at $0-100 \mathrm{~cm}$ for the 48-year old tree plantations (Fig. 3b).

In chronosequence 3, the SOC contents were $10.96-33.77 \mathrm{~g} / \mathrm{kg}$ in the top $10 \mathrm{~cm}$ with a significant increase of more than $200 \%$ (Fig. 4). The variation trend that occurred in chronosequence 3 within the 150-year natural vegetation restoration was similar to the observed trends in chronosequence 1 and chronosequence 2 . The SOC contents significantly increased in the upper layers $(0-50 \mathrm{~cm})$ while had no change in the underlying layers $(50-100 \mathrm{~cm})$ during a long term natural restoration (Fig. 4a). The soil C stocks were $16.09-34.62 \mathrm{Mg} / \mathrm{hm}^{2}$ in $0-10 \mathrm{~cm}$ and $63.34-91.64 \mathrm{Mg} / \mathrm{hm}^{2}$ in $0-100 \mathrm{~cm}$ in chronosequence 3 . The soil $\mathrm{C}$ stocks of all thicknesses 
showed significant increases over the 150 -year period of natural vegetation restoration. However, in the initial 27 years after natural restoration, the soil $\mathrm{C}$ stocks had no significant change. The soil $\mathrm{C}$ stocks in the depth of $0-100 \mathrm{~cm}$ began to increase after 60 years of natural restoration (Fig. 4b).
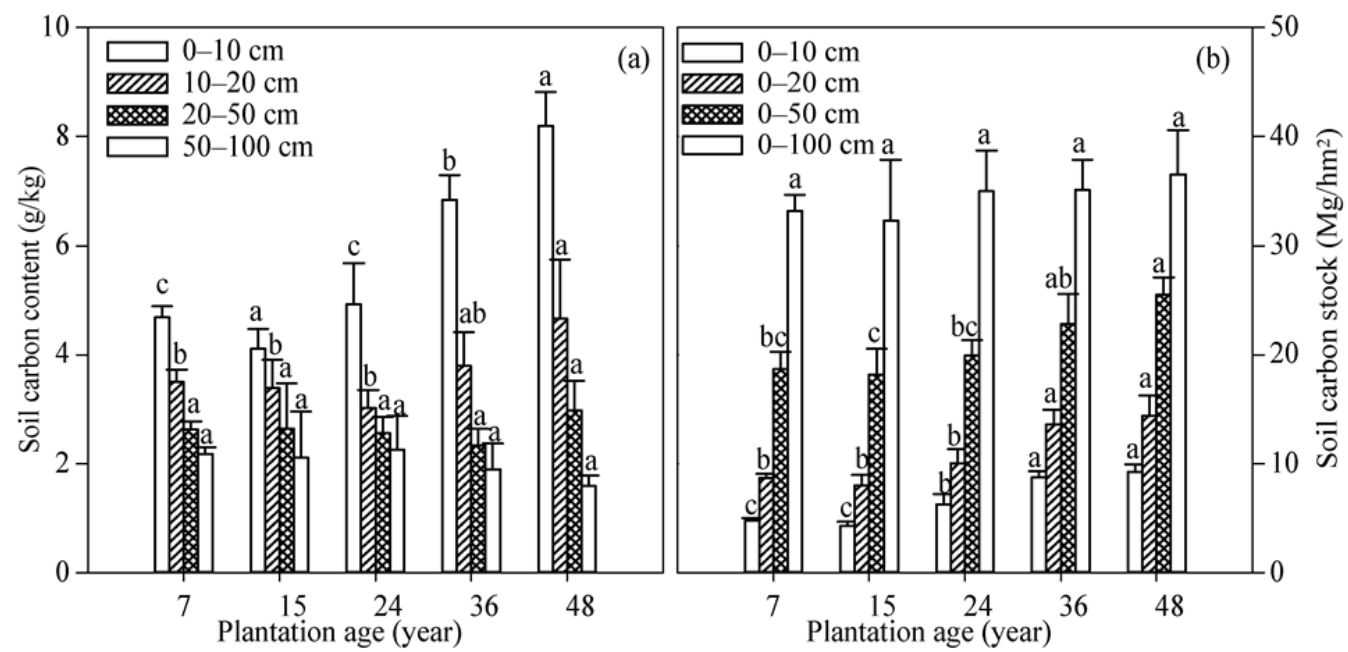

Fig. 3 Changes of SOC content (a) and soil C stock (b) in chronosequence 2. Different letters indicate significant differences among plantation ages based on LSD test, with $P<0.05$.
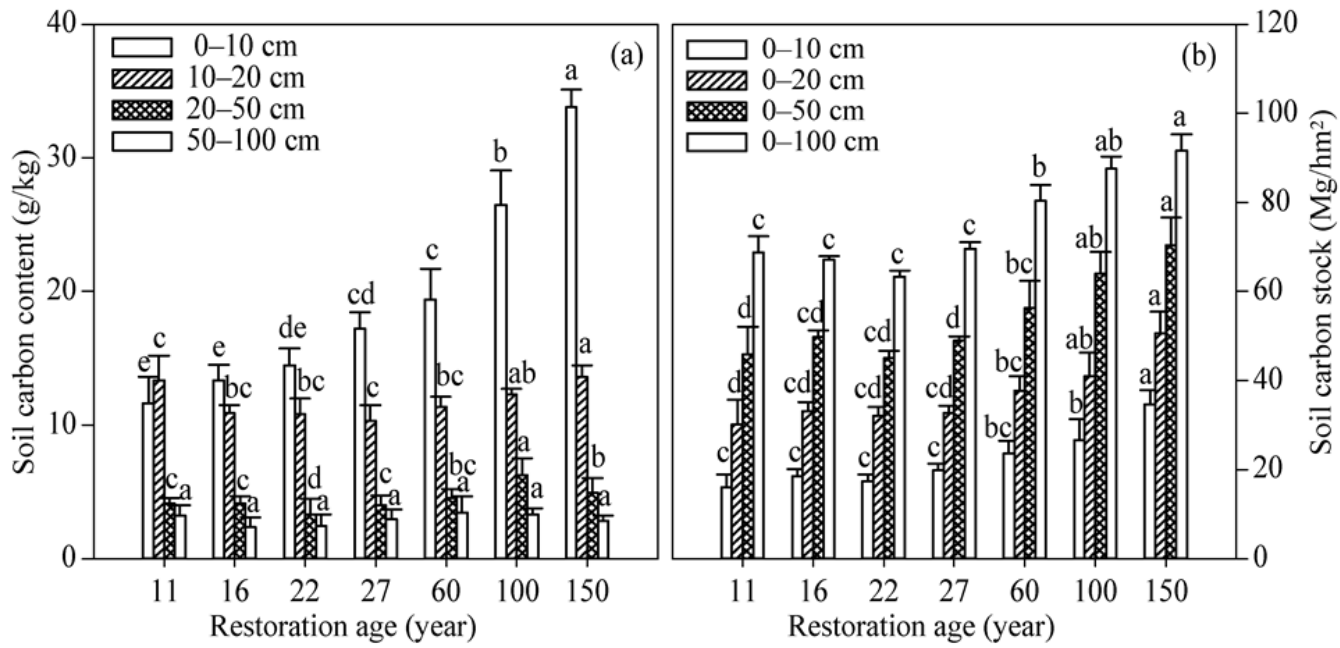

Fig. 4 Changes of SOC content (a) and soil C stock (b) in chronosequence 3. Different letters indicate significant differences among restoration ages based on LSD test, with $P<0.05$.

\subsection{Dynamics of plant C stocks}

In chronosequence 1 (Fig. 5), the biomass $C$ stocks increased from 1.20 to $6.85 \mathrm{Mg} / \mathrm{hm}^{2}$ (Fig. 5a). The above-ground biomass C was from 0.89 to $1.98 \mathrm{Mg} / \mathrm{hm}^{2}$ (an increase of $122.5 \%$ ), while the below-ground biomass C was from 0.31 to $4.86 \mathrm{Mg} / \mathrm{hm}^{2}$ or a 14.7 -fold increase after 30 years of natural vegetation restoration. During the 30 -year period of natural vegetation restoration, the percentage of the above-ground biomass $C$ gradually decreased from $74.2 \%$ to $29.0 \%$, while the below-ground biomass $\mathrm{C}$ increased from $25.8 \%$ to $71.0 \%$ (Fig. $5 \mathrm{~b}$ ).

In chronosequence 2 (Fig. 6), the biomass C stocks increased from 0.35 to $75.23 \mathrm{Mg} / \mathrm{hm}^{2}$ in the 48-year re-vegetation by $R$. pseudoacacia plantation (Fig. 6a). The biomass $\mathrm{C}$ after 48 years was about 214.9 times of that in after 7 years. In contrast to the natural restoration in chronosequence 1 , above-ground biomass of the tree plantation dominated with more than $75 \%$ of the biomass $\mathrm{C}$ stocks during the 48-years tree plantation (Fig. 6b). 


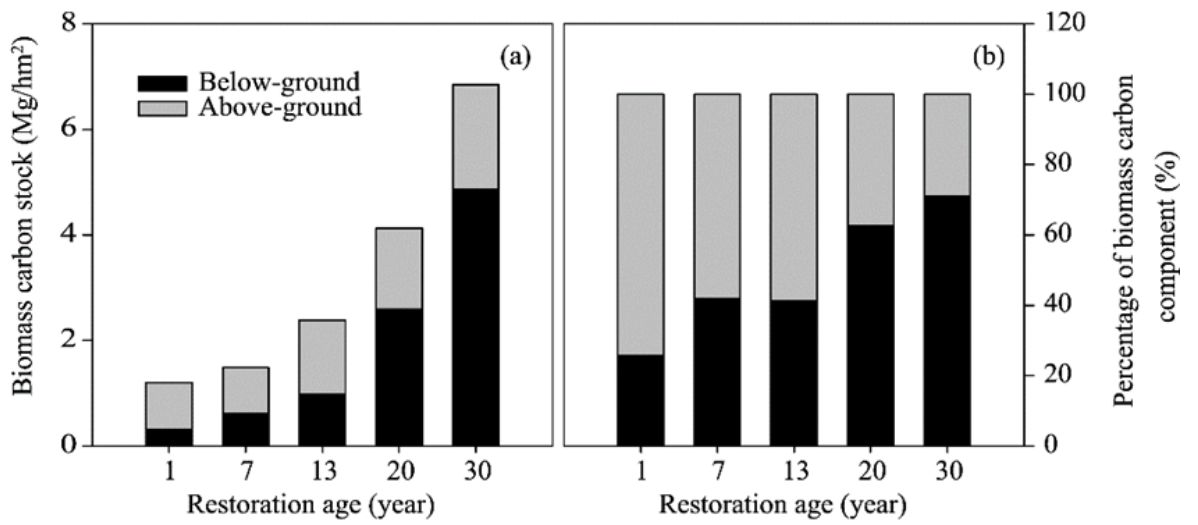

Fig. 5 Changes of above- and below-ground biomass $\mathrm{C}$ stock (a) and their percentages of total biomass $\mathrm{C}$ stock (b) in chronosequence 1

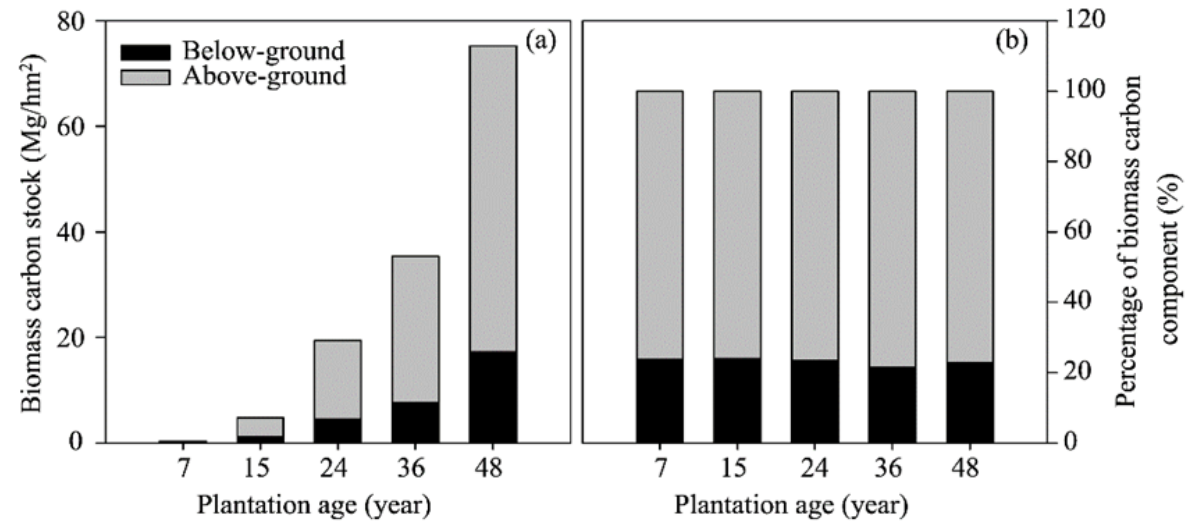

Fig. 6 Changes of above- and below-ground biomass $\mathrm{C}$ stock (a) and their percentages of total biomass $\mathrm{C}$ stock (b) in chronosequence 2

In chronosequence 3 (Fig. 7), the biomass $\mathrm{C}$ stocks increased slowly during the first 27 years, and then rapidly increased after 60 years of natural restoration. The biomass $\mathrm{C}$ stocks increased from 2.09 to $47.62 \mathrm{Mg} / \mathrm{hm}^{2}$ during 150 years of natural restoration (Fig. 7a). The below-ground biomass contributed to about $60 \%$ of the biomass $\mathrm{C}$ stocks in the first 27 years, while it decreased to about $20 \%$ after 60 years restoration (Fig. $7 b$ ).

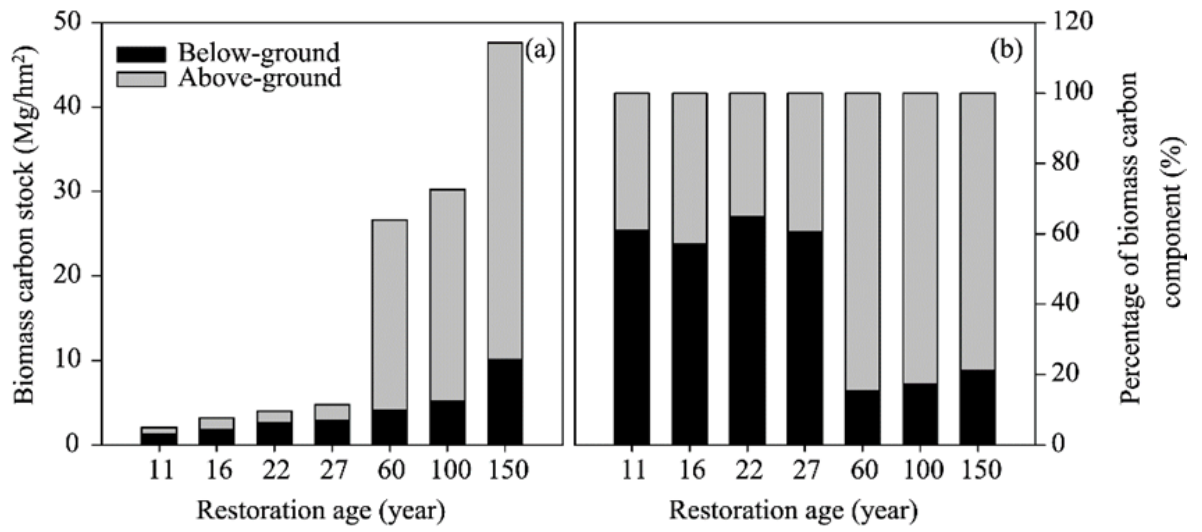

Fig. 7 Changes of above- and below-ground biomass $\mathrm{C}$ stock (a) and their percentages of total biomass $\mathrm{C}$ stock (b) in chronosequence 3 


\subsection{Dynamics of ecosystem C stocks}

In chronosequence 1 , ecosystem $\mathrm{C}$ stocks showed different trends when different soil depths were selected from the 30-year natural vegetation restoration (Fig. 8). Ecosystem $\mathrm{C}$ stocks gradually increased when the upper soil layers $(0-10$ and $0-20 \mathrm{~cm})$ were considered. However, ecosystem $\mathrm{C}$ stocks decreased in the initial 7-year restoration, and then increased during the period from 7 to 30 years at soil depths of down to 50 and $100 \mathrm{~cm}$. Overall, soil organic C more strongly contributed to ecosystem C stocks when biomass $\mathrm{C}$ was evaluated in the 30-year natural vegetation restoration.
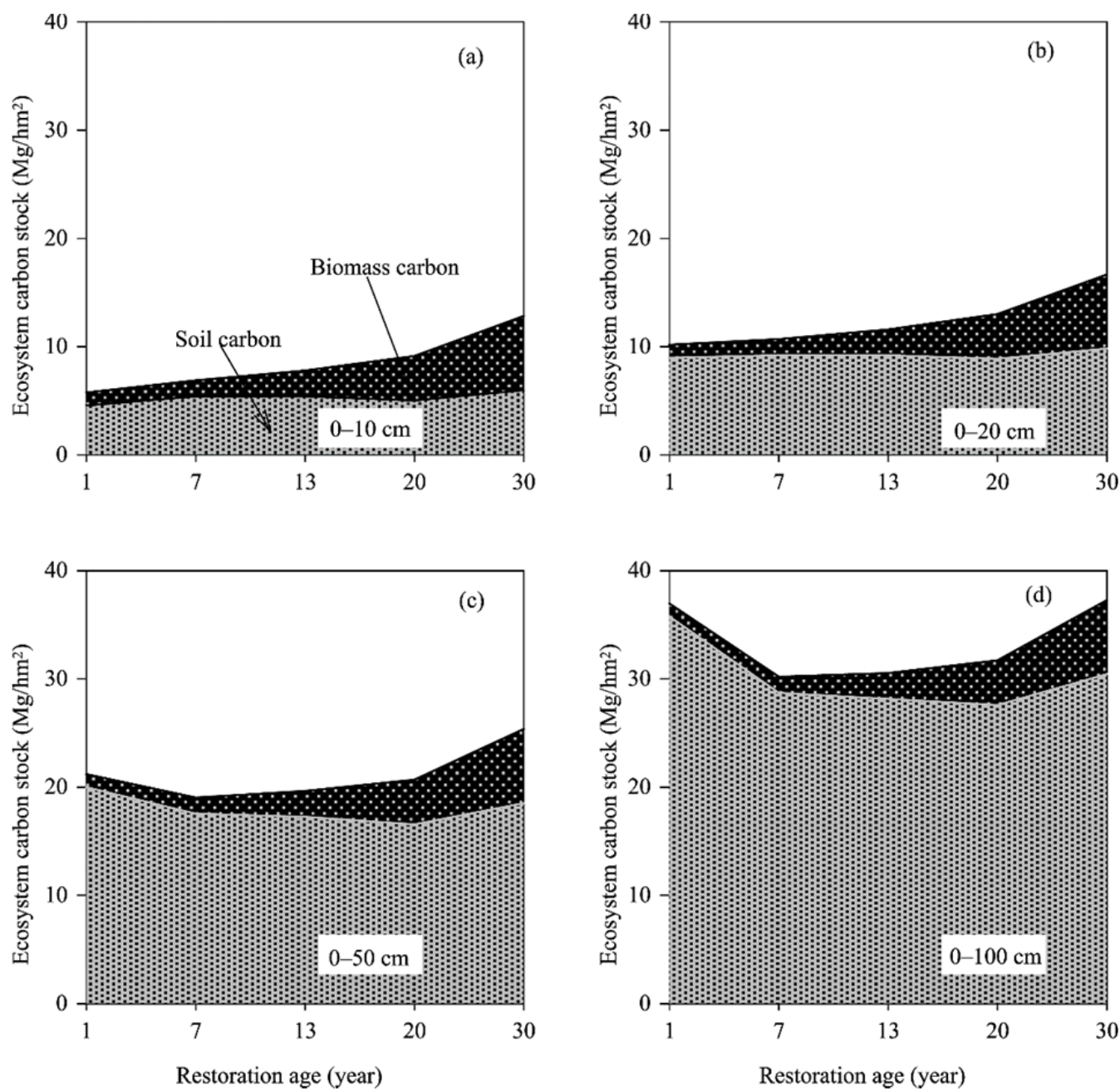

Fig. 8 Changes of ecosystem (plant and soil) C stock with different soil sampling depths at 0-10 (a), 0-20 (b), 0-50 (c), and 0-100 cm (d) in chronosequence 1. Biomass and soil C stock were indicated with arrows. Plant biomass includes two parts of above- and below-ground biomass.

In chronosequence 2 , ecosystem $\mathrm{C}$ stocks consistently showed increasing trends in the 48 -year re-vegetation tree plantations regardless of the soil depth (Fig. 9). Biomass C continuously increased and played a dominant role in the 48-year restoration period with percentages of $89.1 \%-67.3 \%$ at the four soil depths while soil $\mathrm{C}$ stocks did not change much during 48 years tree plantations.

In chronosequence 3, ecosystem $\mathrm{C}$ stocks generally showed increasing trends with natural restoration ages within the four soil depths (Fig. 10). The variations could be divided into two phases. Ecosystem $\mathrm{C}$ stocks fluctuated within the 27-year restoration and then rapidly increased from the 60 - to 150 -year restorations. Soil $\mathrm{C}$ contributed to ecosystem $\mathrm{C}$ stocks with the average percentages of $67.4 \%-85.0 \%$ of the four soil depths. 

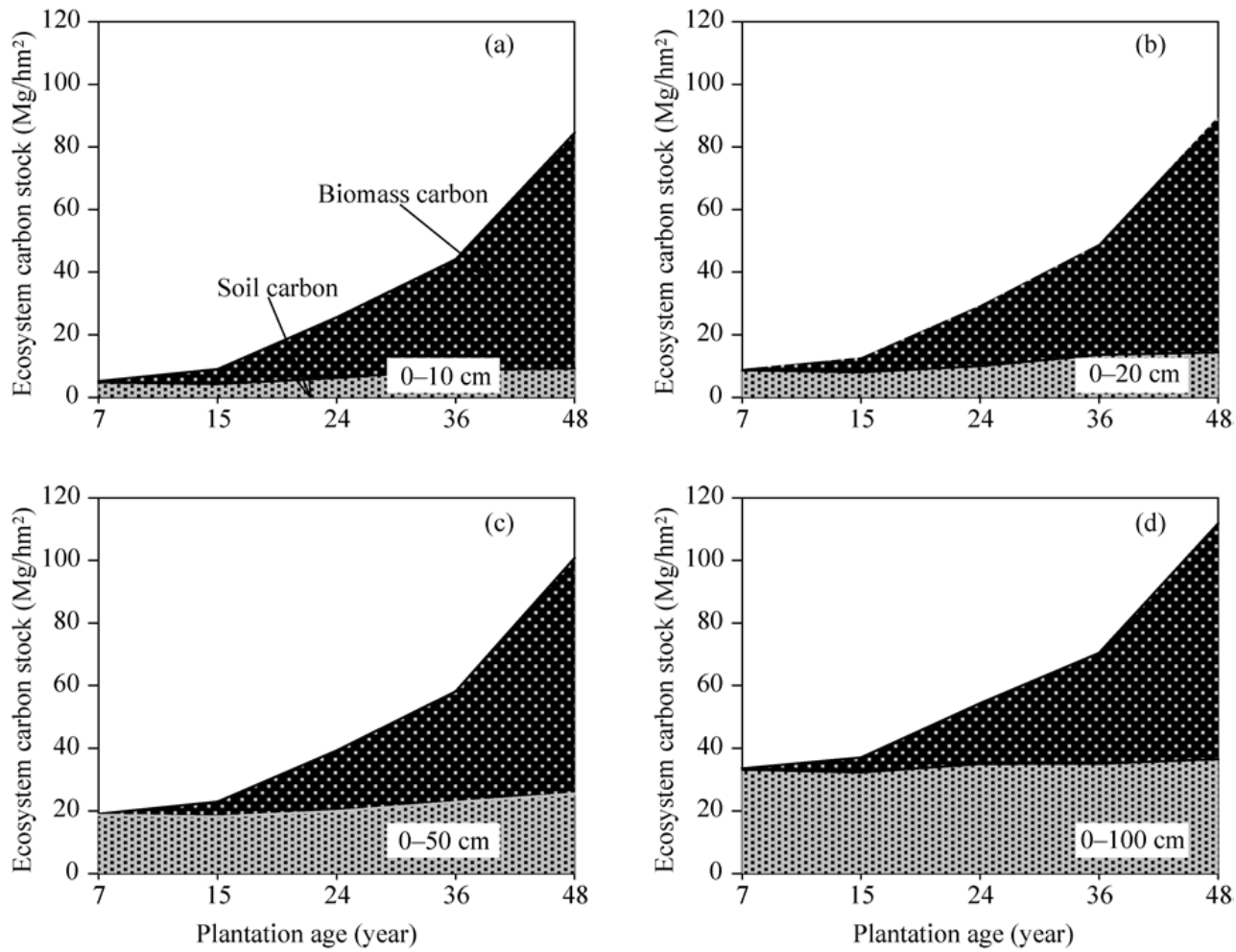

Fig. 9 Changes of ecosystem (plant and soil) $\mathrm{C}$ stocks with different soil sampling depths at 0-10 (a), 0-20 (b), 0-50 (c), and 0-100 cm (d) in chronosequence 2. Biomass and soil C stock were indicated with arrows. Plant biomass includes two parts of above- and below-ground biomass.
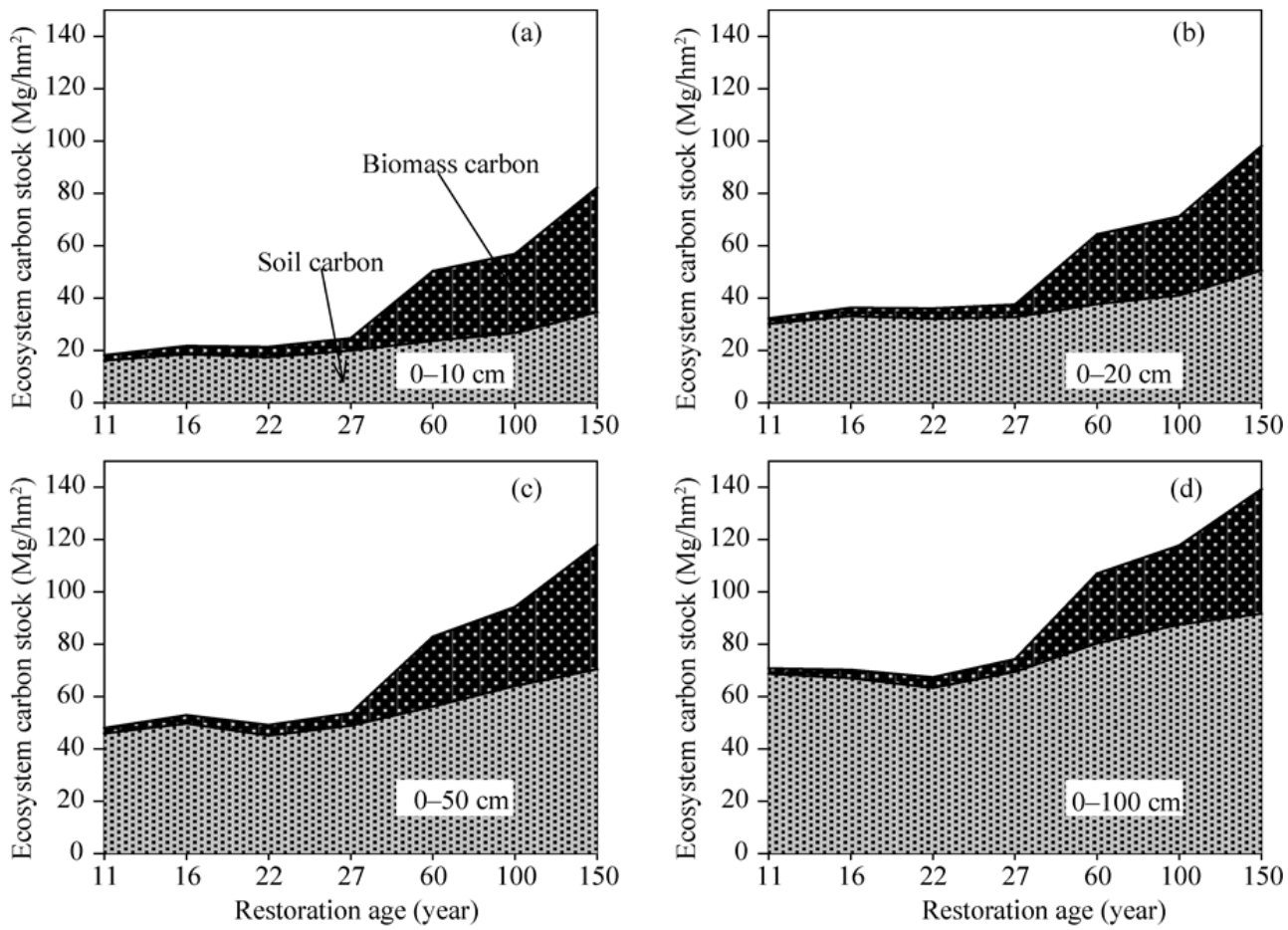

Fig. 10 Changes of ecosystem (plant and soil) C stocks with different soil sampling depths at 0-10 (a), 0-20 (b), 0-50 (c), and $0-100 \mathrm{~cm}(\mathrm{~d})$ in chronosequence 3 . Biomass and soil $\mathrm{C}$ stock were indicated with arrows. Plant biomass includes two parts of above- and below-ground biomass. 


\section{Discussion}

\subsection{Effects of restoration models on C stocks}

The study showed that natural vegetation restoration had different effects on ecosystem $\mathrm{C}$ stocks with tree plantation (Figs. 8 and 9). Tree plantation was able to sequester $\mathrm{C}$ earlier in the re-vegetation cycle and had higher ecosystem $\mathrm{C}$ storage than natural vegetation restoration within a time scale of decades. The large differences in ecosystem $\mathrm{C}$ stocks under the two restoration models were mainly because of rapidly increased biomass $C$ during tree plantation, whereas the differences in soil $\mathrm{C}$ stocks were small. These findings were also supported by previous studies (Richter et al., 1999; Li et al., 2005; Hiltbrunner et al., 2013; Tremblay and Ouimet, 2013). Tremblay and Ouimet (2013) found that white spruce (Picea glauca) plantations were more effective as $\mathrm{C}$ sinks than natural vegetation restoration in Canada, and most of the $\mathrm{C}$ stocks accumulated in the vegetation within a 50 years restoration. Hiltbrunner et al. (2013) reported that tree plantation on sub-alpine pastures would induce a large $\mathrm{C}$ sink in tree biomass but have little effect on soil C stock. Li et al. (2005) also found no significant difference in SOC between a 20 -year-old pine plantation and a secondary forest originating from the same abandoned farmland in the wet tropics of Puerto Rico. On Chinese Loess Plateau, vegetation C stocks have obviously increased after the initiative of Grain to Green program while the soil $\mathrm{C}$ stocks have not changed significantly (Feng et al., 2013). Herbaceous vegetation occupied the study region for at least 50 years before the secondary forest established on the abandoned cultivated land (Table 2). Due to the low productivity of the herbaceous in the early natural restoration stage, both the $\mathrm{C}$ sequestered in biomass and litters returned to soil are small, while afforestation with fast-growing tree species has a much higher productivity and litter restitution than herbaceous vegetation under natural restoration. Thus, tree plantation would sequester more carbon than natural vegetation restoration in a short restoration period. However, natural vegetation showed a great potential in carbon sequestration in a long term restoration (Fig. 10). Unfortunately, the tree plantation history was less than 100 years in the study region and therefore its long term effects on carbon sequestration could not be evaluated in the study.

\subsection{Effects of restoration age on $\mathrm{C}$ stock}

Restoration age was an important factor that affects ecosystems $\mathrm{C}$ sequestration (Guo and Gifford, 2002; Yang et al., 2011; Li et al., 2012). In our study, biomass C stocks of the three chronosequences increased with the restoration age and the greatest biomass increase occurred in chronosequence 2 under the tree plantation (Figs. 5-7). In contrast, the biomass $\mathrm{C}$ increased slowly in chronosequence 1 and chronosequence 3 in the first 30 years of natural restoration. However, it sharply increased after more than 60 years when vegetation types in the chronosequence 3 shifted from grass to forest (Table 2). Similar findings were reported in other studies as well. In a review, Yang et al. (2011) found that vegetation C pools increased over time in most ecosystems. In the eastern Canada, Tremblay and Ouimet (2013) found that the biomass $\mathrm{C}$ increased with age within 50 years vegetation restoration, and tree plantation sequestrated more vegetation $C$ stocks than natural restoration. In south China, Wang et al. (2013) reported that biomass C stocks increased from 22.0 to $151.5 \mathrm{Mg} / \mathrm{hm}^{2}$ after Casuarina equisetifolia planted for 18 years. Overall, restoration age has positive effects on accumulation of biomass carbon because of the rapid increase in leaf area index and available soil nutrients along age gradient (Yang et al., 2011).

In contrast to the vegetation $\mathrm{C}$ pool, dynamics of soil $\mathrm{C}$ stocks were more complex during natural restoration, with the following four temporal patterns: (1) increase (Deng et al., 2013b; Dou et al., 2013); (2) decrease (Kirschbaum et al., 2008); (3) negligible change (Sartori et al., 2007); and (4) initial decrease during the early stage, and then gradual increase to net $\mathrm{C}$ gains (Ritter, 2007; Lu et al., 2013). The initial decrease of soil C could last for 3-35 years or more after agricultural abandonment (Paul et al., 2002). In our study, the soil $\mathrm{C}$ pools in $0-100 \mathrm{~cm}$ depth exhibited similar temporal patterns among the three restoration chronosequences with the soil C stocks generally declining or unchanged in the early stages, and then increased in the late 
stages (Figs. 2b, 3b and 4b). The temporal pattern was especially obvious in chronosequence 3 of the long term natural vegetation restoration, which indicated that restoration age had important influences on dynamics of soil $\mathrm{C}$ pools. A recent synthesis study on the Loess Plateau also revealed that $\mathrm{C}$ stock changes in the soil depth of $0-100 \mathrm{~cm}$ were similar to pattern (4) as mentioned above (Deng et al., 2014). The decrease of soil C stocks was mainly attributed to the low $\mathrm{C}$ input of new established vegetation and higher $\mathrm{C}$ loss from soil disturbance in the early restoration stage (Don et al., 2009; Laganière et al., 2010). Thus, a time lag was often observed between plant production and soil $\mathrm{C}$ accumulation. Lu et al. (2013) observed that it would take 10-15 years for SOC accumulation trend turned from decrease to increase for $R$. pseudoacacia afforestation on the Loess Plateau of China. In our study, a time lag about 15-30 years was also observed between plant production and soil $\mathrm{C}$ accumulation in $0-100 \mathrm{~cm}$ depth under natural restoration (Figs. 8d, 9d and 10d).

\subsection{Effects of sampling depth on C stock}

In the study, soil $\mathrm{C}$ stocks were distinctively varied with the soil depth (Figs. 2-4). Soil C stocks generally showed increasing trends from $0-10$ and $0-20 \mathrm{~cm}$ soil layers, while they exhibited an initial decrease and then increase trends from $0-50$ and $0-100 \mathrm{~cm}$ soil layers under natural restoration although the decreasing trends were not significant in chronosequence 2 and chronosequence 3. In agreed with our study, Deng et al. (2014) reported that soil C sequestration after land use change varied with soil sampling depths, and the top soil is more active at sequestering $C$ than the deeper soil (Guo and Gifford, 2002). Wang et al. (2011) found that soil organic $C$ accumulated in the surface soil layer $(0-20 \mathrm{~cm})$, but no consistent change occurred in deeper layers after larch plantations in northeastern China. Kalinia et al. (2013) observed that soil $\mathrm{C}$ stocks increased in the top mineral layer $(0-10 \mathrm{~cm})$, while it decreased from 10-50 cm layers after 68 years of self-restoration in the Taiga zone of Russia. A study on the Loess Plateau of China also revealed that crop-derived $\mathrm{C}$ concentration only decreased in the $0-20 \mathrm{~cm}$ soil depth, and it was almost unchanged in the $20-80 \mathrm{~cm}$ even after 200 years of afforestation (Wei et al., 2012). Moreover, there was a time lag in soil $\mathrm{C}$ sequestration between the sub and top soil (Figs. 2-4). The changes in soil $\mathrm{C}$ stock were determined by both the input and decomposition of organic matters. For the top soil, with increased time, there was an increase in C inputs, and also changes in microclimatic environment which is conducive to enhanced organic matter protection and promoted SOC accumulation (Laganière et al., 2010; Deng et al., 2014). However, for the subsoil, the input of $\mathrm{C}$ from rhizo-deposition and hydrological leaching of dissolved organic $\mathrm{C}$ was too little to match the ongoing decomposition of the original $\mathrm{C}$, thus led to the initial decrease of soil C in the early restoration stage (Richter et al., 1999). In our study, soil C stock dynamics were inconsistent in the topsoil and subsoil during vegetation restoration, which suggests that different $\mathrm{C}$ sequestration mechanisms were acting in the top and sub soil layers. In addition, our result supported that restoration age was a determining factor that affected the change of deep soil organic $\mathrm{C}$ after afforestation of former agricultural land (Shi et al., 2013).

\section{Conclusions}

We found that vegetation restoration on abandoned cultivated land could promote $\mathrm{C}$ sequestration, and the restoration model (natural restoration or tree plantation) has an important effect on dynamics of $\mathrm{C}$ stocks. Tree plantation had higher $\mathrm{C}$ sequestration than natural restoration within a time scale of decades due to the rapid increase of biomass. However, soil $\mathrm{C}$ sequestration under natural restoration is nearly equivalent to soil $\mathrm{C}$ sequestration under tree plantation. For ecosystem $\mathrm{C}$ sequestration, tree plantation was more effective than natural vegetation restoration. Restoration age showed a different effect on dynamics of soil and biomass $\mathrm{C}$ stocks. Biomass $\mathrm{C}$ stocks of the three chronosequences increased with time although tree plantation accumulated much more biomass than natural vegetation in the early decades. In contrast, soil $\mathrm{C}$ stocks changed with sampling depths during vegetation restoration. Soil $\mathrm{C}$ stocks generally showed increasing trends in 0-20 cm depths, while they exhibited an initially decrease and then increase in 0-100 cm depths. 
There was a long term effect of natural restoration on deeper soil $\mathrm{C}$ sequestration. A time lag about 15-30 years was observed between plant production and soil $\mathrm{C}$ accumulation in the soil depth of 0 $100 \mathrm{~cm}$.

\section{Acknowledgements}

This study was funded by the National Natural Science Foundation of China (41301610, 41501094, 41330858), the Key Research Program of the Chinese Academy of Sciences (KZZD-EW-04), the Natural Science Basic Research Plan in Shaanxi Province of China (2014JQ5170) and the open foundation of State Key Laboratory of Soil Erosion and Dryland Farming on the Loess Plateau (A318009902-1510). We thank Ms. ZHENG Yaliang for her help in handling samples and laboratory assay. The authors are grateful for the constructive comments from the reviewers and editors.

\section{References}

China's State Forestry Administration. 2011. Carbon sink metering and monitoring guidelines of afforestation projects. http://www.xjlyt.gov.cn/get/zwgk/20110324.doc. (in Chinese)

Deng L, Wang K B, Chen M L, et al. 2013b. Soil organic carbon storage capacity positively related to forest succession on the Loess Plateau, China. Catena, 110: 1-7.

Deng L, Liu G B, Shangguan Z P. 2014. Land-use conversion and changing soil carbon stocks in China's 'Grain-for-Green' Program: a synthesis. Global Change Biology, 20(11): 3544-3556.

Don A, Rebmann C, Kolle O, et al. 2009. Impact of afforestation-associated management changes on the carbon balance of grassland. Global Change Biology, 15(8): 1990-2002.

Don A, Schumacher J, Freibauer A. 2011. Impact of tropical land-use change on soil organic carbon stocks-a meta-analysis. Global Change Biology, 17(4): 1658-1670.

Dou X L, Deng Q, Li M, et al. 2013. Reforestation of Pinus massoniana alters soil organic carbon and nitrogen dynamics in eroded soil in south China. Ecological Engineering, 52: 154-160.

Eggleston H S, Buendia L, Miwa K, et al. 2006. IPCC Guidelines for National Greenhouse Gas Inventories. Hayama, Japan. Institute for Global Environmental Strategies.

Feng X M, Fu B J, Lu N, et al. 2013. How ecological restoration alters ecosystem services: an analysis of carbon sequestration in China's Loess Plateau. Scientific Reports, 3: 2846.

Foote R L, Grogan P. 2010. Soil carbon accumulation during temperate forest succession on abandoned low productivity agricultural lands. Ecosystems, 13(6): 795-812.

Guidi C, Vesterdal L, Gianelle D, et al. 2014. Changes in soil organic carbon and nitrogen following forest expansion on grassland in the Southern Alps. Forest Ecology and Management, 328: 103-116.

Guo L B, Gifford R M. 2002. Soil carbon stocks and land use change: a meta analysis. Global Change Biology, 8(4): 345-360.

Hiltbrunner D, Zimmermann S, Hagedorn F. 2013. Afforestation with Norway spruce on a subalpine pasture alters carbon dynamics but only moderately affects soil carbon storage. Biogeochemistry, 115(1): 251-266.

Jandl R, Rodeghiero M, Martinez C, et al. 2014. Current status, uncertainty and future needs in soil organic carbon monitoring. Science of the Total Environment, 468-469: 376-383.

Jia X X, Wei X R, Shao M A, et al. 2012. Distribution of soil carbon and nitrogen along a revegetational succession on the Loess Plateau of China. Catena, 95: 160-168.

Jin Z, Dong Y S, Wang Y Q, et al. 2014. Natural vegetation restoration is more beneficial to soil surface organic and inorganic carbon sequestration than tree plantation on the Loess Plateau of China. Science of the Total Environment, 485-486: 615-623.

Kalembasa S J, Jenkinson D S. 1973. A comparative study of titrimetric and gravimetric methods for the determination of organic carbon in soil. Journal of the Science of Food and Agriculture, 24(9): 1085-1090.

Kalinina O, Chertov O, Dolgikh A V, et al. 2013. Self-restoration of post-agrogenic Albeluvisols: Soil development, carbon stocks and dynamics of carbon pools. Geoderma, 207: 221-233.

Kirschbaum M U F, Guo L B, Gifford R M. 2008. Observed and modelled soil carbon and nitrogen changes after planting a Pinus radiata stand onto former pasture. Soil Biology and Biochemistry, 40(1): 247-257.

Laganière J, Angers D A, Paré D. 2010. Carbon accumulation in agricultural soils after afforestation: a meta-analysis. Global Change Biology, 16(1): 439-453.

Li D J, Niu S L, Luo Y Q. 2012. Global patterns of the dynamics of soil carbon and nitrogen stocks following afforestation: a 
meta-analysis. New Phytologist, 195(1): 172-181.

Li Y Q, Xu M, Zou X M, et al. 2005. Comparing soil organic carbon dynamics in plantation and secondary forest in wet tropics in Puerto Rico. Global Change Biology, 11(2): 239-248.

Liu Z P, Shao M A, Wang Y Q. 2011. Effect of environmental factors on regional soil organic carbon stocks across the Loess Plateau region, China. Agriculture, Ecosystems \& Environment, 142(3-4): 184-194.

Lorenz K, Lal R, Shipitalo M J. 2011. Stabilized soil organic carbon pools in subsoils under forest are potential sinks for atmospheric $\mathrm{CO}_{2}$. Forest Science, 57(1): 19-25.

Lu N, Liski J, Chang R Y, et al. 2013. Soil organic carbon dynamics of black locust plantations in the middle Loess Plateau area of China. Biogeosciences, 10(11): 7053-7063.

Marín-Spiotta E, Sharma S. 2013. Carbon storage in successional and plantation forest soils: a tropical analysis. Global Ecology and Biogeography 22(1): 105-117.

Paul K I, Polglase P J, Nyakuengama J G, et al. 2002. Change in soil carbon following afforestation. Forest Ecology and Management, 168(1-3): 241-257.

Poeplau C, Don A, Vesterdal L, et al. 2011. Temporal dynamics of soil organic carbon after land-use change in the temperate zone-carbon response functions as a model approach. Global Change Biology, 17(7): 2415-2427.

Richter D D, Markewitz D, Trumbore S E, et al. 1999. Rapid accumulation and turnover of soil carbon in a re-establishing forest. Nature, 400(6739): 56-58.

Ritter E. 2007. Carbon, nitrogen and phosphorus in volcanic soils following afforestation with native birch (Betula pubescens) and introduced larch (Larix sibirica) in Iceland. Plant and Soil, 295(1-2): 239-251.

Sartori F, Lal R, Ebinger M H, et al. 2007. Changes in soil carbon and nutrient pools along a chronosequence of poplar plantations in the Columbia Plateau, Oregon, USA. Agriculture Ecosystems \& Environment, 122(3): 325-339.

Shi S W, Zhang W, Zhang P, et al. 2013. A synthesis of change in deep soil organic carbon stores with afforestation of agricultural soils. Forest Ecology and Management, 296: 53-63.

Tremblay S, Ouimet R. 2013. White spruce plantations on abandoned agricultural land: Are they more effective as c sinks than natural succession? Forests, 4(4): 1141-1157.

Wang Y F, Fu B J, Lü Y H, et al. 2011. Effects of vegetation restoration on soil organic carbon sequestration at multiple scales in semi-arid Loess Plateau, China. Catena, 85(1): 58-66.

Wang F M, Xu X, Zou B, et al. 2013. Biomass accumulation and carbon sequestration in four different aged Casuarina equisetifolia coastal shelterbelt plantations in south China. PLoS ONE, 8(10): e77449.

Wei J, Cheng J M, Li W J, et al. 2012. Comparing the effect of naturally restored forest and grassland on carbon sequestration and its vertical distribution in the Chinese loess plateau. PLoS ONE, 7(7): e40123.

Wei X R, Qiu L P, Shao M A, et al. 2012. The accumulation of organic carbon in mineral soils by afforestation of abandoned farmland. PLoS ONE, 7(3): e32054.

Yang Y H, Luo Y Q, Finzi A C. 2011. Carbon and nitrogen dynamics during forest stand development: a global synthesis. New Phytologist, 190(4): 977-989.

Zhang C, Liu G B, Xue S, et al. 2013. Soil organic carbon and total nitrogen storage as affected by land use in a small watershed of the Loess Plateau, China. European Journal of Soil Biology, 54: 16-24. 